\title{
A SURVEY OF THE PHYSICAL FITNESS LEVEL OF THE MEN'S BASKETBALL TEAM NATIONAL SPORTS WEEK (PON) BANGKA BELITUNG 2020
}

\author{
Ridho Pamungkas*, Angkit Kinasih, Kristiawan P. A. Nugroho \\ Christian University Satya Wacana, Salatiga, Indonesia \\ E-mail: ridhopamungkas45@gmail.com
}

\begin{abstract}
Abstrak
Kebugaran fisik adalah kemampuan seseorang untuk melakukan aktivitas sehari-hari dengan mudah tanpa kelelahan yang berlebihan dan masih memiliki cadangan energi untuk melakukan aktivitas lain. Melalui kebugaran fisik yang baik, tujuannya adalah untuk menciptakan generasi masa depan yang unggul dalam semua aspek yang bisa diwujudkan. Masalah yang dirumuskan adalah bagaimana tingkat kebugaran jasmani Tim Basket Putra PRA PON Bangka Belitung 2020. Tujuan penelitian ini adalah untuk mengetahui tingkat kebugaran jasmani PRA PON Tim Basket Putra Bangka Belitung 2020. Populasi dalam penelitian ini adalah Tim Bola Basket Putra 2020 dari PRA PON Bangka Belitung dengan 12 atlet. Sampel dalam penelitian ini berjumlah 12 atlet. Teknik pengambilan sampel yang digunakan adalah total sampling. Metode pengumpulan data menggunakan metode survei menggunakan metode Tes Kebugaran Fisik Indonesia (TKJI) untuk usia 18-21 tahun dan dokumentasi. Dapat disimpulkan bahwa kondisi fisik adalah dasar yang harus dimiliki dalam setiap olahraga, terutama bola basket, karena kondisi fisik merupakan keseluruhan komponen yang tidak dapat dipisahkan, baik untuk peningkatan maupun pemeliharaan prestasi.
\end{abstract}

\section{Kata Kunci: Level, Kebugaran Fisik}

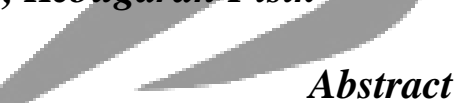

Physical fitness is the ability of a person to carry out daily activities easily without excessive fatigue and still has a reserve of energy to do other activities. Through good physical fitness, the aim is to greate a future generation excels in all aspects can be realized. The problem formulated is how the level of physical fitness of the PRA PON Bangka Belitung Men's Basketball Team 2020. The aim of this study is to determine the level of physical fitness of the PRA PON Bangka Belitung Men's Basketball Team 2020. The population in this study is Men's Basketball Team 2020 of PRA PON Bangka Belitung with 12 athletes. The sample in this study amounted to 12 athletes. The sampling technique used is total sampling. The method of data collection uses the survey method using the Indonesian Physical Fitness Test (TKJI) method for ages 18-21 years and documentation. It was concluded that physical condition is the basis that must be had in every sport, especially basketball, because physical condition is a unified whole of components that cannot be separated, both for improvement and maintenance of achievement.

\section{Keywords: Physical Fitness, Level}

\section{Introduction}

The more people do physical training, it means that the more successful the development of physical fitness and the level of physical fitness in the community, Bafirman (2008) as well as helping to improve the physical quality of the community. Coaching physical fitness can be done with a variety of

PJKR

http://jurnal.unimed.ac.id/2012/index.php/jpehr 
physical exercises or sports, Rubianto Hadi (2010). Basically, various types of exercises or sports to improve physical fitness can be used as a means of training, one of them in basketball, PERBASI (2004).

Physical fitness can be grouped into two categories, namely physical fitness related to skills including speed, agility, explosive power, coordination, and balance and physical fitness related to health include heart endurance, muscle strength, body balance, muscular endurance, and endurance body flexibility, Wiguna, I. B (2017). This aspect of fitness is absolutely necessary especially for athletes because it plays an important role in determining the process and outcome of a match, Sukadiyanto (2011).

M. Sajoto (1988) Physical conditions for athletes, in this case are basketball athletes, play an important role because the intensity of the current basketball game is required to be able to compete with a fast rhythm (Running Game). Therefore, every basketball player is required to have excellent physical condition which is useful for supporting individual performance in a team. Some things that need to be considered in an effort to get excellent physical fitness include doing strength training in the form of push up to train arm and shoulder muscle strength, sit ups to train abdominal strength, back up to train back muscle strength, speed training by doing exercises running short distances to long distances, endurance exercises with weight training types, and flexibility exercises such as stretching, Ardle, et al (1981).

Satya Wacana Salatiga basketball athlete who will have a competence of national sport week (PON) Bangka Belitung in 2020 needs to be physically prepared so that it can show optimal performance. One effort that can be done is to conduct a study of the level of physical fitness. This physical fitness level test can be used as a study for basketball coaches to see the physical performance of athletes in an effort to improve aspects of physical fitness in the period before and when competing, Dangsinal Moeloek (1984). The theneral physical fitmess test is based on the Indonesian Physical Fitness Test, especially for athletes aged 18-21 years. These aspects of testing include (1) running 60 meters, (2) body lift /pull up, (3) lying down /sit up, (4) vertical jumping, and (5) running 1,200 meters.

Based on this background, the formulation of the problem that arises is how the level of physical fitness of basketball athletes who will compete in the pre-Bangka Belitung National Sports Week (PON) in 2020. The purpose of this research is to the level of physical fitness of basketball athletes who will compete in the pre-Bangka Belitung National Sports Week (PON) in 2020. Through this research it is expected to provide knowledge and input for trainers to pay attention to the physical fitness of each athlete, assist in the implementation of training activities and physical fitness development, and can be used as a material for consideration for coaching and enhancing further training programs, Syafruddin (2011). The results of this study can also be used as a picture to improve physical 
fitness for athletes who are still considered lacking and can optimize the physical fitness of athletes who are included in good / prime condition.

\section{Method}

The research method used is descriptive research with a quasi-experimental survey test model. Respondents in this study were basketball athletes Satya Wacana from Satya Wacana Christian University who were involved in the basketball team pre-National Sports Week (PON) Bangka Belitung 2020 totaling 12 people.

The main criteria for selecting respondents in this study were registered as Satya Wacana Salatiga basketball team athletes, male athletes who were involved as basketball players in the pre-Bangka Belitung National Sports Week (PON) 2020, and a maximum age of 19-21 years in 2019.

The main variables to be investigated are the level of physical fitness with instruments including (1) running 60 meters, (2) body lift /pull up, (3) lying down /sit up, (4) vertical jumping, and (5) running 1,200 meters. The research data will be analyzed descriptively statistically using Microsoft Excel application which is displayed in tables and graphs with stages (1) calculating test scores from each test, (2) categorizing the physical fitness level of each athlete for each type of test, and (3) calculate the percentage of total physical fitness level achievement with the formula $\mathrm{P}=(\mathrm{F} / \mathrm{N}) \times 100 \%$. Then, categorize the overall physical fitness results and individual test items using a scale of 5.

Figure 1. Categorize The Overall Physical Fitness Results and Individual Test Items, Sudijono (2015)

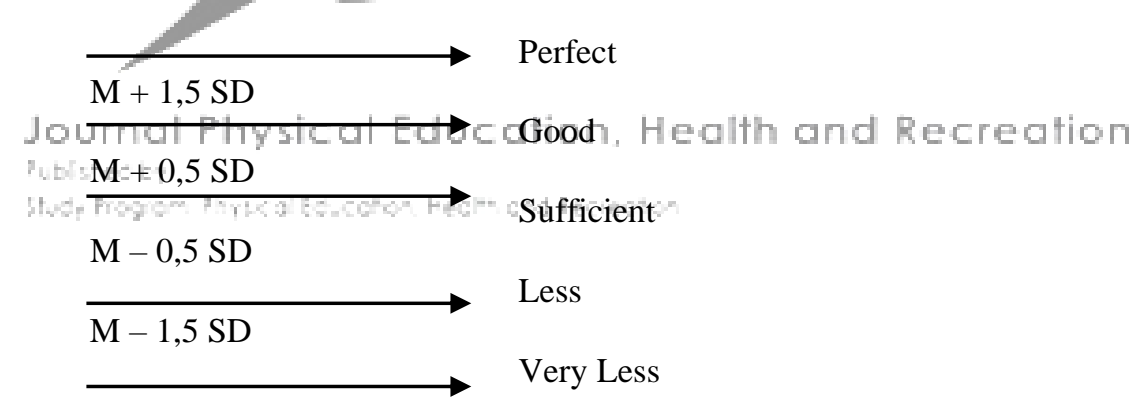

\section{Discussion}

Level of Physical Fitness Men's Basketball Team Pre-National Sports Week (PON) Bangka Belitung 2020 Based on data analysis of the results of research on the physical fitness level of the men's basketball team Pre-National Sports Week (PON) Bangka Belitung 2020, which consists of 60 meters running test, Pull Up, Sit Up, Vertical Jump, and running 1,200 meters, a maximum score of $=60.72$, a minimum score of $=39.67$, an average of $=50.00$ and a standard deviation of $=5.70$. Based on the analysis of data on the Physical Fitness Level of 
the Bangka Belitung Men's National Sports Week (PON) 2020, it shows an average of $=50.00$ or categorized as sufficient.

Table 1. Physical Fitness Level of the Bangka Belitung Men's National Sports Week Sports Week

\begin{tabular}{|c|c|c|c|c|}
\hline \multirow[t]{2}{*}{ No } & \multirow{2}{*}{$\begin{array}{c}\text { Interval } \\
\text { Class }\end{array}$} & \multicolumn{2}{|c|}{ Frequency } & \multirow[t]{2}{*}{ Classification } \\
\hline & & Absolute & Relatifely (\%) & \\
\hline 1 & $>58,55$ & 1 & 8,33 & Perfect \\
\hline 2 & $52,85-58,54$ & 3 & 25,00 & Good \\
\hline 3 & $47,15-52,84$ & 5 & 41,67 & Sufficient \\
\hline 4 & $41,45-47,14$ & 2 & 16,67 & Less \\
\hline 5 & $<41,44$ & 1 & 8,33 & Very Less \\
\hline & Amount & 12 & 100,00 & \\
\hline
\end{tabular}

Based on table 1 above, that the frequency distribution of the results of the test results of the physical fitness level of the men's basketball team Pre-National Sports Week (PON) Bangka Belitung 2020, obtained interval classes that are above 58.55 with an excellent classification of 1 person $(8,33 \%)$, interval classes 52.85-58.54 with good classifications of 3 people (25.00\%), interval classes 47.15-52.84 with enough classifications of 5 people $(41.67 \%)$, interval classes $41,45-47,14$ with a classification of less than 2 people (16.67\%), and interval classes that are under 41.44 with a classification of less than 1 person $(8.33 \%)$.

Based on the analysis of data on the Physical Fitness Level of the Bangka Belitung National Sports Week Men's Sports Week (PON) Team in 2020, it shows an average of $=50.00$ or categorized as sufficient. For more details, each test item indicator will be elaborated as follows:

\section{Run 60 Meter}

Based on the 60 meter running test results from 12 men's basketball team Bangka Belitung National Sperts Week-(PON) 2020, a maximum score of $=7.40$ seconds' is obtained, a minimum score of $=6.12$ seconds, an average of $=6,98$ seconds and standard deviation of $=0.32$ seconds. Based on the results of the analysis of 60-meter running test data, showing an average of $=6.98$ seconds or categorized as sufficient.

Table 2. 60-meter Running Test Frequency Distribution Based on age (19-21 years)

\begin{tabular}{ccccc}
\hline No & $\begin{array}{c}\text { Imterval Class } \\
\text { (Second) }\end{array}$ & \multicolumn{2}{c}{ Frequency } & Classification \\
\cline { 3 - 4 } & & Absolute & $\begin{array}{c}\text { Relatifely } \\
(\boldsymbol{\%})\end{array}$ & \\
\hline 1 & $<6,49$ & 1 & 8,33 & Perfect \\
\hline 2 & $6,50-6,81$ & 2 & 16,67 & Good \\
\hline 3 & $6,82-7,14$ & 7 & 58,33 & Sufficient \\
\hline 4 & $7,15-7,46$ & 2 & 16,67 & Less \\
\hline 5 & $>7,47$ & 0 & 0,00 & Very Less \\
\hline & Amount & 12 & 100,00 & \\
\hline
\end{tabular}

PJKR_

http://jurnal.unimed.ac.id/2012/index.php/jpehr 
2. Pull Up

Based on the results of the Pull Up test for 1 minute from 12 men's basketball teams Bangka Belitung National Sports Week (PON) in 2020, a maximum score of $=23.00$ is obtained, a minimum score of $=3.00$, an average of $=10,00$ and the standard deviation of $=5.20$. Based on the results of Pull Up test data analysis, it shows an average of $=10.00$ or categorized as sufficient.

Table 3. Frequency Distribution of Pull Up Tests Based on age (19-21 years)

\begin{tabular}{ccccc}
\hline No & $\begin{array}{c}\text { Imterval Class } \\
\text { (Second) }\end{array}$ & \multicolumn{2}{c}{ Frequency } & Classification \\
\cline { 3 - 4 } & $>18$ & 1 & 8,33 & \\
\hline 1 & Absolute & $\begin{array}{c}\text { Relatifely } \\
(\%)\end{array}$ & \\
\hline 2 & $13-17$ & 1 & 8,33 & Perfect \\
\hline 3 & $7-12$. & 7 & 58,33 & Sufficient \\
\hline 4 & $2-6$. & 3 & 25,00 & Less \\
\hline 5 & $<1$ & 0 & 0,00 & Very Less \\
\hline & Amount & 12 & 100,00 & \\
\hline
\end{tabular}

Based on table 1 above, that the frequency distribution of Pull Up test data results from 12 men's basketball teams Pre- National Sports Week (PON) Bangka Belitung 2020, obtained interval classes that are above 18 with an excellent classification of 1 person $(8,33 \%)$, class intervals $13-17$ with a good classification of 1 person $(8.33 \%)$, interval classes $7-12$ with a sufficient classification of 7 people $(58.33 \%)$, interval classes $2-6$ with a classification of less than 3 people $(25.00 \%)$, and interval classes that are under 1 with a very low classification of 0 people $(0.00 \%)$.

\section{Sit Up}

Based on the results of the Sit Up test for 1 minute from 12 men's basketball team Pre-National Sports Week (PON) Bangka Belitung 2020, obtained a maximum score of $=41.00$, minimum score of $=25.00$, an average of $=$ 33, 17 and the standard deviation of $=4.49$. Based on the analysis of the Sit Up test data, it shows an average of $=33.17$ or is categorized as sufficient.

Table 4. Frequency Distribution of Sit Up Tests Based on age (19-21 years).

\begin{tabular}{ccccc}
\hline No & $\begin{array}{c}\text { Interval } \\
\text { Class }\end{array}$ & \multicolumn{2}{c}{ Frequency } & Classification \\
\cline { 3 - 4 } & & Absolute & Relatifely (\%) & \\
\hline 1 & $>40$ & 1 & 8,33 & Perfect \\
\hline 2 & $35-39$ & 4 & 33,33 & Good \\
\hline 3 & $31-34$ & 3 & 25,00 & Sufficient \\
\hline 4 & $26-30$ & 3 & 25,00 & Less \\
\hline 5 & $<25$ & 1 & 8,33 & Very Less \\
\hline & Amount & 12 & 100,00 & \\
\hline
\end{tabular}

PJKR

http://jurnal.unimed.ac.id/2012/index.php/jpehr 


\section{Vertical Jump}

Based on the results of the Vertical Jump test of 12 men's basketball teams in the Bangka Belitung National Sports Week (PON) 2020, a maximum score of $=$ $74.00 \mathrm{~cm}$ is obtained, a minimum score of $=61.00 \mathrm{~cm}$, an average of $=66.33 \mathrm{~cm}$ and standard deviation of $=4.23 \mathrm{~cm}$. Based on the results of the Vertical Jump test data analysis, it shows an average of $=66.33$ or is categorized as sufficient.

Table 5. Frequency Distribution of Vertical Jump TestsBased on age (19-21 years).

\begin{tabular}{ccccc}
\hline No & $\begin{array}{c}\text { Interval } \\
\text { Class }\end{array}$ & \multicolumn{2}{c}{ Frequency } & Classification \\
\cline { 3 - 4 } & $\begin{array}{c}\text { Centimeter) } \\
\text { Censolute }\end{array}$ & $\begin{array}{c}\text { Relatifely } \\
(\boldsymbol{\%})\end{array}$ & \\
\hline 1 & $>73$ & 1 & 8,33 & Perfect \\
\hline 2 & $68-72$ & 3 & 25,00 & Good \\
\hline 3 & $64-67$ & 5 & 41,67 & Sufficient \\
\hline 4 & $60-63$ & 3 & 25,00 & Less \\
\hline 5 & $<59$ & 0 & 0,00 & Very Less \\
\hline & Amount & 12 & 100,00 & \\
\hline
\end{tabular}

Based on table 1 above, that the frequency distribution of Vertical Jump test results from 12 men's basketball teams Pre-National Sports Week (PON) Bangka Belitung 2020, obtained interval classes that are above $73 \mathrm{~cm}$ with an excellent classification of 1 person $(8,33 \%), 68-72 \mathrm{~cm}$ interval class with good classification of 3 people $(25.00 \%), 64-67 \mathrm{~cm}$ interval class with enough classification of 5 people $(41.67 \%)$, interval class of $60-63 \mathrm{~cm}$ with less classification of 3 people $(25.00 \%)$, and interval classes under $59 \mathrm{~cm}$ with very little classification of 0 people $(0.00 \%)$.

\section{Run 1.200 Meters}

Based on the 1,200 meter running test results from 12 men of the Bangka Belitung dational Sports dWeek $(P Q N)$ in 2020 , , maximum $_{r}$ scere $_{\circ}$ of $=6.55$ minutes was obtained, a minimum score of $=5.57$ minutes, an average of $=6,08$ minutes and standard deviation of $=0.34$ minutes. Based on the analysis of the running test data of 1,200 meters, it shows an average of $=6.08$ minutes or is considered sufficient.

Table 6. Frequency Distribution of the 1,200 Meter Running Test Based on age (19-21 years).

\begin{tabular}{ccccc}
\hline No & $\begin{array}{c}\text { Interval } \\
\text { Class }\end{array}$ & \multicolumn{2}{c}{ Frequency } & Classification \\
\cline { 3 - 4 } & (Minute) & Absolute & $\begin{array}{c}\text { Relatifely } \\
(\%)\end{array}$ & \\
\hline 1 & $<5,57$ & 1 & 8,33 & Perfect \\
\hline 2 & $5,58-5,91$ & 2 & 16,67 & Good \\
\hline 3 & $5,92-6,25$ & 6 & 50,00 & Sufficient \\
\hline 4 & $6,26-6,59$ & 3 & 25,00 & Less \\
\hline 5 & $>6,60$ & 0 & 0,00 & Very Less \\
\hline & Amount & 12 & 100,00 & \\
\hline
\end{tabular}

Based on table 1 above, that the frequency distribution of 1,200 meters of test results from 12 men's basketball teams in the Pacific Islands National Sports 
Week (PON) in 2020, obtained interval classes under 5.57 minutes with excellent classification of 1 people (8.33\%), class intervals5.58-5.91 minutes with good classifications of 2 people (16.67\%), class intervals of 5.92-6.25 minutes with enough classifications of 6 people (50.00\%), class intervals of 6.26-6.59 minutes with less classifications of 3 people $(25.00 \%)$, and interval classes that are above 6.60 minutes with less classifications of 0 people $(0.00 \%)$.

Based on the results of research on the physical fitness level of the men's basketball team Pre-National Sports Week (PON) Bangka Belitung 2020, shows an average of $=50.00$ or categorized as sufficient. The category is still not maximal, because to obtain a very good category must be a score above 58.55.

Physical condition is a must-have in every sport. General physical condition can be interpreted by the state or physical ability. According to Bafirman (2013) said, "physical condition is the most dominant basic preparation to be able to make maximum physical appearance". Physical condition is a unified whole of components which cannot be separated, both for improvement and in maintaining performance. Components of the physical condition of the muscular concept include: Velocity/Speed, Flexibility, Agility, Balance and Coordination.

According to Jonath and Krempel in Syafruddin (2011) said, "physical conditions are distinguished by narrow and broad understanding". In a narrow sense the physical condition is a condition that includes strength, speed and endurance. However, in a broad sense it includes all three elements and is added by elements of flexibility and coordination. According to Bompa in Sukadiyanto (2011) said, "the biomotor component is the overall physical condition of the sportsman, because almost all motion activities in sports always contain elements of strength, duration, speed, and complex motion that requires the breadth of joint motion".

According to Wiguna (2017) said, "physical condition training refers to a program that is carried oufsystematically, planned and progressively which aims to improve the functional abilities of the entire body system so that athlete performance is increasing". Furthermore, Wiguna (2017) said, specifically if the athlete's physical condition is good, there will be:

1. Increase in the ability of the circulatory system and the work of the heart.

2. Increases in strength, flexibility, stamina, speed and other physical components.

3. Better economy of motion at practice.

4. Faster recovery of body organs after exercise.

5. Rapid response from bodily organisms if at any time such a response is needed.

6. Psychologically athletes who have good physical condition will be more confident in facing challenges and matches.

According to Bafirman and Agus (2008) said, "the purpose of fostering physical conditions depends on a person, such as fostering fitness or physical 
fitness of a person, increasing the dominant biomotoric abilities needed to improve the performance of the sport that is involved". In determining the purpose of fostering physical conditions, it is important to note the following basic training:

1. To improve physical development in general. Good physical condition is the main basis for someone good for physical fitness, especially for athletes to achieve the highest performance.

2. Promotes typical physical development.

3. Perfect the technique of the chosen sport.

4. To improve and perfect strategies and learn techniques.

5. To shape personality and behavior as an athlete's attitude that is sportsmanship.

6. To ensure team readiness.

7. To build health.

8. To avoid injury.

9. To increase knowledge or athletes about the basis of training in terms of physiology.

\section{Conclusion}

It was concluded that physical condition is the basis that must be had in every sport, especially basketball, because physical condition is a unified whole of components that cannot be separated, both for improvement and maintenance of achievement. In general, the overall leyel of physical fitness of the men's basketball team in Bangka Belitung National Sports Week (PON) in 2020 is still not optimal because it is still categorized as sufficient, so that it does not guarantee the readiness of athletes to achieve the desired achievements. Therefore, physical condition plays an important role in displaying techniques and adjusting tempo in the game, so that the-physical condition must be possessed byothe athlete in facing the competition, so that achievement can be maximized.

Based on the results of research on the physical fitness level of the men's basketball team Pre-National Sports Week (PON) Bangka Belitung 2020, which includes: running 60 meters, Pull Up, Sit Up, Vertical Jump and running 1,200 meters, then it can be concluded that the overall level physical fitness of the men's basketball team in the Pre-Sports National Week (PON) Bangka Belitung 2020 is in the category sufficient.

\section{References}

Ardle, Mc., Katch, WD, F.I., Katch, 1981. Exercise Physiology: Energy, Nutrition and Human Performance. Philadelpia: Lea \& Febiger.

Bafirman, 2013. Fisiologi Olahraga. Malang: Wineka Media.

Bafirman dan Agus A, 2008. Pembentukan Kondisi Fisik. Padang: FIK UNP. 
Dangsina Moeloek, 1984. Dasar Fisiologi Kesegaran Jasmani dan Latihan Fisik.

Jakarta: Bagian Ilmu Faal Fakultas Kedokteran Universitas Indonesia.

M. Sajoto, 1988. Pembinaan Kondisi Fisik Dalam Olahraga. Jakarta: Depdikbud. PERBASI, 2004. Bola Basket Untuk Semua. Jakarta: Bidang III PB. PERBASI.

Rubianto Hadi, 2010. Ilmu Kepelatihan Dasar. Semarang: Unnes Press.

Sudijono, Anas, 2015. Pengantar Evaluasi Pendidikan. Jakarta: PT. Raja Grafindo Persada.

Sukadiyanto, 2011. Pengantar Teori dan Metodologi Melatih Fisik. Yogyakarta: FIK-UNY.

Syafruddin, 2011. Ilmu Kepelatihan Olahraga, Teori dan Aplikasinya Dalam Pembinaan Olahraga. Padang: UNP Press.

Wiguna, I. B, 2017. Teori dan Aplikasi Latihan Kondisi Fisik. Depok: Rajawali Pers.

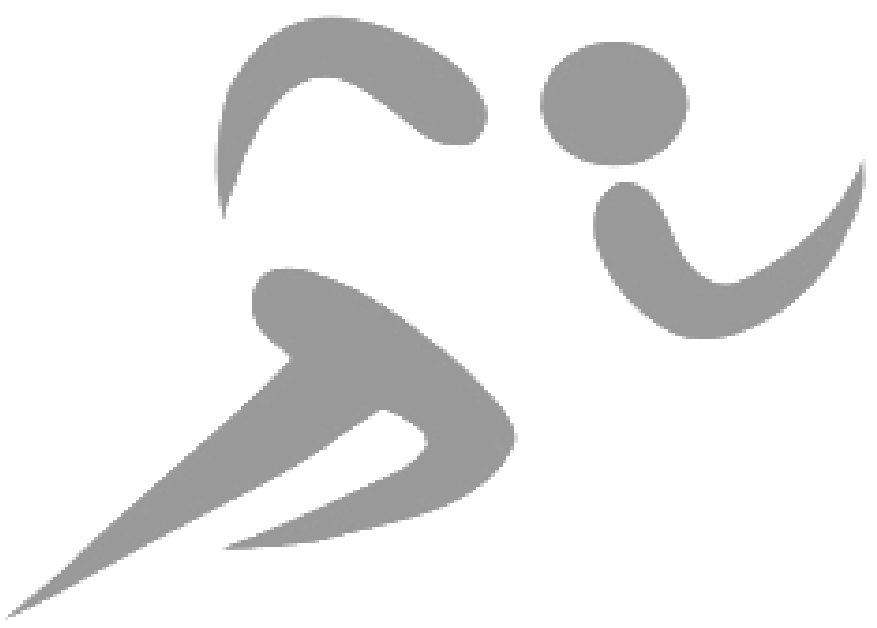

Journal Physical Education, Health and Recreation

pubisesticis

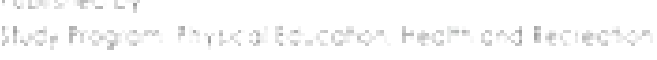

PJKR_

http://jurnal.unimed.ac.id/2012/index.php/jpehr 